\title{
IMPLEMENTASI MARKETING MIX TABUNGAN HAJI PADA PT. PANIN BANK SYARIAH, TBK CABANG MALANG
}

\author{
Uun Dwi Al Muddatstsir \\ Universitas Airlangga Surabaya \\ uundwi@gmail.com
}

Firda Azkiya Safitri Su'ud

Universitas Islam Negeri (UIN) Maulana Malik Ibrahim

Early Ridho Kismawadi

IAIN Langsa

kismawadi@gmail.com

Fadlil Abdani

Universitas Airlangga Surabaya

\section{j-EBIS}

Jurnal Ekonomi dan Bisnis

Islam

Volume : 2

Nomor : 1

Halaman : 1-28

Langsa, April 2017

ISSN : 2502-1397

E-ISSN : 2540-8100

\section{Abstract:}

This study develops an implementation issue marketing mix hajj savings on PT. Islamic Bank Panin Tbk, Malang Branch. This study by the increase in background backs hajj savings of $40 \%-60 \%$ in 2014-2015 and wanted to know about the application of the marketing mix in PT. Islamic Bank Panin Tbk, Malang Branch. The result of this research is PT. Islamic Bank Panin Tbk branch Malang that all the marketing mix can already be applied properly by PT. Bank Panin Tbk Syariah Branch Malang, but its implementation must be adapted to target such people and places that will beaddressed and PT. Bank Panin Tbk Syariah Branch Malang providesinnovations in its products to be in demand by customers

such as giving rewards to customers and marketing mix is applied to serve the activities provided to customers.

Keywords : Marketing Mix, Haji Savings

\section{PENDAHULUAN}

Perkembangan perbankan tidak terlepas dari perkembangan perdagangan. Seiring dengan perkembangan perdagangan dunia, maka perkembangan perbankan pun semakin pesat. Perkembangan perdagangan yang semula hanya berkembang di daratan Eropa akhirnya menyebar ke Asia Barat. Bank-bank yang sudah terkenal pada saat itu di benua Eropa adalah Bank Venesia tahun 1171, kemudian menyusul Bank of Genoa dan Bank of Barcelona pada tahun 1320. Sebaliknya, perkembangan perbankan di daratan Ingris baru dimulai pada abad ke-16. Namun, karena Negara-negara Eropa seperti Inggris, Perancis, Belanda, Spanyol, atau Portugis begitu aktif mencari 
daerah perdagangan yang kemudian menjadi daerah jajahannya, maka perkembangan perbankan pun ikut dibawa ke negara jajahannya (Kasmir, 2010: 14).

Di Indonesia, pengembangan ekomomi islam telah diadopsi ke dalam kerangka besar kebijakan ekonomi. Paling tidak, Bank Indonesia sebagai otoritas perbankan di tanah air telah menetapkan perbankan syariah sebagai salah satu pilar penyangga dual-banking system dan mendorong pangsa pasar bank-bank syariah yang lebih luas sesuai cetak biru perbankan syariah (Bank Indonesia, 2002).

Harus kita akui pertumbuhan bank syariah di negara kita merupakan fenomena yang sangat menarik. Bayangkan jumlah penduduk di negara kita yang kini telah mencapai 200 juta jiwa sungguh merupakan peluang pasar yang sangat potensial menggiurkan dari posisi profitabilitasnya. Dari sisi lain kita bisa melihat tingginya profitabilitas bisnis bank syariah yang tercermin dari banyaknya pelaku perbankan asing yang ikut andil dalam membuka unit bank yang berlandaskan syariah dan menerima untung yang tidak sedikit. Di antaranya adalah Citibank, ABN Amro, dan HSBC yang merupakan contoh bank yang sukses merambah bisnis bank syariah di Timur Tengah dan Malaysia (Amir Machmud dan rukmana, 2010: 6)

Setiap perusahaan ingin mempertahankan perusahaannya di lingkungan pasar yang daya saingnya setiap hari nya semakin berkembang. Oleh karena itu strategi pemasaran yang baik akan menciptakan keuggulan bersaing yang baik, bukan hanya sementara. Memang tidak mudah untuk menciptakan keunggulan bersaing yang baik dan sulit ditiru oleh pesaing, tetapi jika sesekali berhasil, maka kesuksesan perusahaan dapat bertahan lebih lama.

Penggunaan bauran pemasaran (marketing mix) dalam dunia perbankan dilakukan dengan menggunakan konsep-konsep yang sesuai dengan kebutuhan bank. Dalam praktiknya konsep bauran pemasran terdiri dari bauran pemasaran untuk produk yang berupa barang maupun jasa. Khusus untuk produk yang berbentuk barang jasa diperlukan konsep yang sedikit berbeda dengan produk barang. Kotler menyebutkan konsep pemasaran (marketing mix) terdiri dari empat P (4P), yaitu: product (produk), Price (harga), Place (tempat/saluran distribusi), Promotion (promosi) (Kasmir, 2010: 119)

Sebuah analisis tentang problem-problem yang dihadapi oleh perusahaan-perusahaan besar dan perusahaan kecil menunjukan bahwa ada kemungkinan untuk mengurangi jumlah variabel dalam marketing mix menjadi 4 variabel pokok yaitu : product (produk), Price (harga), Place (tempat/saluran distribusi), Promotion (promosi) (Winardi 1989:329) 
Firda, Early, Uun, Fadlil: Marketing Mix

Sedangkan Boom dan Bitner menambah dalam bisnis jasa, bauran pemasaran di samping 4P seperti yang dikemukakan di atas, ada tambahan dengan 3P, yaitu : People (orang), Physical evidence (bukti fisik), Process (proses) (Kasmir, 2010: 120)

PT. Panin Bank Syariah mempunyai banyak produk yang ditawarkan kepada masyarakat. Tetapi di PT. Panin Bank Syariah mempunyai produk unggulan yaitu produk pembiayaan tabungan haji. Karena setiap tahun produk ini nasabah tabungan haji selalu meningkat.

Akad yang digunakan oleh PT. Panin Bank Syariah pada tabungan haji yaitu akad wadi'ah yad dhamanah dimana sistem pembagian keuntungan bukan bagi hasil namun berupa bonus yang akan diberikan kepada nasabah namun tidak diperjanjikan di awal.

Menurut hasil wawancara dengan Pak Sigit (29-02-2016) selaku salah satu tim marketing haji di Panin Bank Syariah menyampaikan bahwa jumlah nasabah tabungan haji dari tahun 2014 - 2015 meningkat sekitar 40\% - 60\%. Akan tetapi tim marketing haji untuk mendapatkan nasabah haji melalui cara yang berbeda-beda lebih kepada cara pendekatan kepada nasabah atau KBIH.

Penelitian ini berupaya untuk memaksimalkan penerapan marketing mix pada PT. Panin Bank Syariah agar peneliti bisa mengetahui lebih dalam tentang strategi yang digunakan oleh tim marketing haji PT. Panin Bank Syariah sehingga produk yang ditawarkan bisa lebih diminati nasabah.

Dari beberapa paparan di atas, peneliti ingin mengeatahui lebih dalam tentang penerapan marketing mix pada produk tabungan haji yang diterapakan pada PT. Panin Bank Syariah Cabang.

\section{KAJIAN PUSTAKA}

\section{Pengertian Pemasaran Bank}

Pengertian pemasaran bagi setiap perusahaan tidak ada perbedaan. Hanya saja yang menjadi masalah adalah penerapan pemasaran untuk setiap jenis perusahaan memiliki karakteristik tersendiri. Misalnya, pemasaran yang dijalankan untuk perusahaan yang menghasilkan produk berupa barang tentu akan sangat berbeda dengan perusahaan yang memiliki produk jasa seperti perusahaan keuangan. Bank sebagai perusahaan yang bergerak dibidang keuangan produk yang diperjualbelikan merupakan jasa keuangan. Oleh karena itu, perlakuan pemasaran terhadap dunia perbankanpun sedikit berbeda dengan perusahaan lainnya. 
Secara umum pengertian pemasaran bank adalah Suatu proses untuk menciptakan dan memepetukarkan produk atau jasa bank yang ditujukan untuk memenuhi kebutuhan dan keinginan nasabah dengan cara memberikan kepuasan (Kasmir, 2010: 54)

\section{Tujuan Pemasaran Bank}

Dalam praktiknya tujuan suatu perusahaan dapat bersifat jangka pendek maupun jangka panjang. Dalam jangka pendek biasanya hanya bersifat sementara dan juga dilakukan sebagai langkah untuk mencapai tujuan jangka panjang.Demikian pula dalam hal menjalankan kegiatan pemasaran suatu perusahaan memiliki banyak kepentingan untuk mencapai tujuan yang diharapkan.

\section{Bauran Pemasaran (Marketing Mix)}

Kotler (2000:15) memberikan difinisi mengenai bauran pemasaran sebagai:

Bauran pemasaran adalah perangkat alat pemasaran faktor yang dapat dikendalikan product, price, promotion, dan place yang dipadukan oleh perusahaan untuk menghasilkan respon yang diinginkan dalam pasar sasaran.

Sementara Saladin (2003) memberikan definisi :

Bauran pemasaran (marketing mix) adalah serangkaian dari variabel pemasaran yang dapat dikuasi oleh perusahaan dan digunakan untuk mencapai tujuan dalam pasar sasaran (Nur Rianto Al Arif, 2010: 14)

Berikut ini penjelasan singkat mengenai masing-masing unsur dari marketing mix dari definisi yang dikemukakan oleh Philip Kotler (2000:15) antara lain sebagai berikut:

\section{Product (Produk)}

Produk menurut Philip Kotleradalah : sesuatu yang dapat ditawarkan ke pasar untuk mendapatkan perhatian untuk dibeli, untuk digunakan atau dikonsumsi yang dapat memenuhi keinginan dan kebutuhan. Produk biasanya digunakan untuk dikonsumsi baik untuk kebutuhan rohani maupun jasmani. Untuk memenuhi keinginan dan kebutuhan akan produk, maka konsumenn harus mengorbankan sesuatu sebagai balas jasanya, misalnya dengan cara pemebelian (Kasmir, 2008: 123)

Sedangkan menurut pemasaran syariah, produk konsumen adalah berdaya guna, materi yang dapat dikonsumsi yang bermanfaat, bernilai guna yang menghasilkan perbaikan material, moral, spiritual bagi pelanggan.Sesuatu yang tidak berdaya guna 
Firda, Early, Uun, Fadlil: Marketing Mix

dan dilarang oleh syariah, bukan produk dalam pengertian pemasaran syariah. Dalam pemasran konvensional, produk adalah yang dapat ditukarkan, tetapi produk dalam pemasran syariah adalah produk yang dipertukarkan itu berdaya guna secara agama (Ali Hasan, 2010: 15)

Kita sudah menggolongkan bahwa produk bank merupakan jasa.Kemudian jasa yang ditawarkan dalam bentuk beraneka ragam. Dalam praktik sehari-hari berbagai jenis jasa bank yang ditawarkan kepada masyarakat. Kelengkapan jenis produk yang ditawarkan sangat tergantung dari kemampuan bank dan jenis bank itu sendiri.

Dalam dunia perbankan strategi produk yang dilakukan adalah mengembangkan suatu produk adalah sebagai berikut : (Kasmir, 2010:127-128)

\section{Penentuan Logo dan Moto}

Logo merupakan cirri khas suatu bank, sedangkan moto merupakan serangkaian kata-kata yang berisikan misi dan visi bank dalam melayani masyarakat.Baik logo maupun moto harus dirancang dengan benar.

\section{Menciptakan Merek}

Karena jasa memiliki beraneka ragam, maka setiap jasa harus memiliki nama. Tujuannya agar mudah dikenal dan diingat pembeli.Merek merupakan suatu untuk mengenal barang atau jasa yang dirawarkan. Pengertian merek sering diartikan sebagai nama, istikah, symbol, desain, atau kombinasi dari semuanya.

\section{Menciptakan Kemasan}

Kemasan merupakan pembungkus suatu produk.Dalam dunia perbankan kemasan lebih diartikan kepada pemberian pelayanan atau jasa kepada para nasabah di samping juga sebagai pembungkus untuk beberapa jenis jasanya seperti buku tabungan, cek, bilyet giro, atau kartu kredit.

\section{Keputusan Label}

Label merupakan sesuatu yang dilengketkan pada produk yang ditawarkan dan merupakan bagian dari kemasan. Di dalam label di jelaskan siapa yang membuat, di mana dibuat, kapan dibuat, cara menggunakanya, waktu kedaluarsa, komposisi isi, dan informasi lainnnya.

Menurut Nur rianto Al Arif (2010:16) produk dalam pemasaran syariah adalah berdaya guna, materi yang dapat dikonsumsidan yang mempunyai manfaat, bernilai guna yang menghasilkann perbaikan material, moral, spirituial bagi pelanggan.sebagaimana dapat disimak dalam firman Allah SWT. 
Dalam surah Al-Baqarah (2:173).

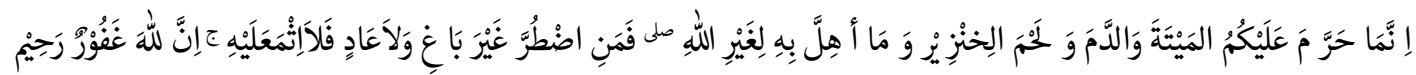

Artinya : "Sesungguhnya Allah hanya mengharamkan bagimu bangkai, darah, daging babi, dan binatang yang (ketika disembelih) disebut (nama) selain Allah, Tetapi barang siapa yang dalam keadaan terpaksa (memakannya) sehingga dia tidak menginginkannya dan tidak (pula) melampaui batas, maka tidak ada dosa baginya. Sesungguhnya Allah Maha Pengampun lagi Maha Penyayang"

\section{Price (Harga)}

Penentuan harga merupakan salah satu aspek penting dalam kegiatan pemasaran. Harga menjadi sangat penting untuk diperhatikan, mengingat harga sangat menentukan laku tidaknya produk dan jasa perbanka. Salah dalam menentukan harga akan berakibat fatal terhadap produk yang ditawarkan nantinya (Kasmir, 2010: 135)

Dalam hadis diceritakan bahwa Abu Hurairah juga menuturkan, pernah ada seorang laki-laki mendatangi Rsulullah SAW la lalu berkata, "Ya Rasulullah, tetapkanlah harga.” Rasulullah menjawab, "Akan tetapi, aku hanya akan berdoa kepada Allah.” Lalu datang orang lain berkata, "Ya Rasulullah, tetapkanlah harga" Beliau menjawab:

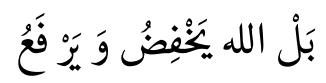

"Akan tetapi, Allahlah Yang menurunkan dan menaikkan harga". (HR Ahmad dan ad-Darimi)

Dari hadis diatas dapat disimpulkan bahwa penetapan harga dengan cara dan karena alasan yang tidak tepat, merupakan suatu ketidakadilan yang akan dituntut pertanggungjawabanya di hadapan Allah.

\section{Place (Tempat/Saluran distribusi)}

Yang dimaksud dengan lokasi bank adalah tempat dimana diperjualbelikannya produk perbankan dan pusat pengendalian perbankan. Dalam praktiknya ada beberapa macam lokasi kantor bank yaitu lokasi kantor pusat, cabang utama, cabang pembantu, kantor kas dengan lokasi mesin-mesin Anjungan Tunai Mandiri (ATM) (Kasmir, 2010: 145).

Bagi perbankan, pemilihan lokasi (tempat) sangat penting, dalam menentukan lokasi pembukaan kantor cabang atau kantor kas termasuk peletakkan mesin ATM, bank harus mampu mengidentifikasi sasaran pasar yang dituju berikut yang sesuai dengan core business dari perusahaan. 


\section{Promotion (Promosi)}

Promosi merupakan sarana yang paling ampuh untuk menarik dan mempertahankan nasabanya.Salah satu tujuan promosi bank adalah menginformasikan segala jenis produk yang ditawarkan dan berusaha menarik calon nasabah yang baru.Dalam kegiatan ini setiap bank berusaha untuk mempromosikan seluruh produk dan jasa yang dimilikinya baik langsung maupun tidak langsung. Kemudian promosi juga berfungsi mengingatkan nasabah akan produk, promosi juga ikut memengaruhi nasabah untuk membeli dan akhirnya promosi juga akan meningkatkan citra bank di mata para nasabahnya (Kasmir , 2010: 155).

Dalam konsep syariah dalam promosi juga dijelaskan dalam Firman Allah Swt AlQur'an surah An-Nisaa' (4:29)

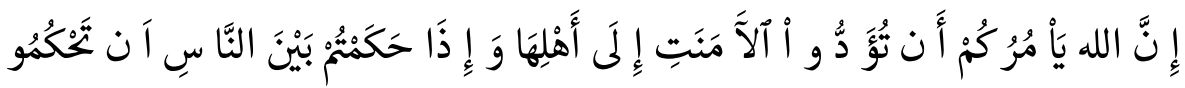

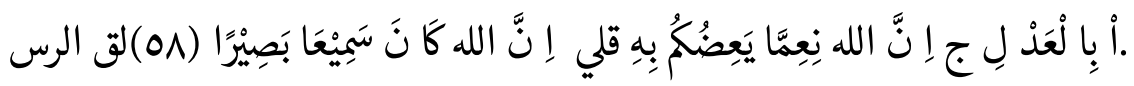

"Hai orang-orang yang beriman, janganlah kamu saling memakan harta sesamamu dengan jalan yang batil, kecuali dengan jalan perniagaan yang dapat berlaku dengan jalan kamu, dan janganlah kamu membunuh dirimu.Sesunggunya Allah adalah maha penyayang kepadamu."

\section{People (Orang)}

Dalam hubungannya dengan pemasaran jasa, people yang berfungsi sebagai service provider sangat memengaruhi kualitas jasa yang diberikan.Keputusan dalam people ini sangat berarti sehubungan dengan seleksi, training, motivasi, dan manajemen sumber daya manusia.

Untuk mencapai kualitas yang terbaik, pegawai harus dilatih untuk menyadari pentingnya pekerjaan mereka, yaitu memberikan konsumen kepuasan dalam memenuhi kebutuhannya.Pentingnya people dalam pemasaran jasa berkaitan erat dengan internal marketing.Internal marketing adalah interaksi atau hubungan antara setiap karyawana dengan departemen dalam suatu perusahaan yang dalam hal ini dapat diposisikan sebagai internal customer dan internal supplier.Tujuan adanya hubungan tersebut adalah untuk mendorong people dalam kinerja memberikan kepuasan kepada konsumen. (Mts.Arif, 2007:98).

Ada empat kriteria peranan atau pengaruh dari aspek people yang memengaruhi konsumen : (Mts.Arif, 2007:98-99)

a. Contractors, people disini berinteraski langsung dengan konsumen dalam frekuensi 
yang cukup sering sangat memengaruhi keputusan konsumen untuk membeli.

b. Modifier, mereka tidak secara langsung memengaruhi konsumen tetapi cukup sering berhubungan dengan konsumen, misalnya resepsionis.

c. Influence, mereka memengaruhi konsumen dalam keputusan untuk membeli, tetapi tidak kontak secara langsung dengan konsumen.

d. Isolated People, disini tidak secara langsung ikut serta dalam marketing mix dan juga tidak sering bertemu dengan konsumen. Misalnya, karyawan bagian administrasi penjualan, SDM, dan data processing.

Ayat-ayat Al-Qur'an yang menjelaskan tentang SDM yang tepat. Allah Saw berfirman

$$
\begin{aligned}
& \text { Al-Qur'an surah An-Nisaa' (4:58) }
\end{aligned}
$$

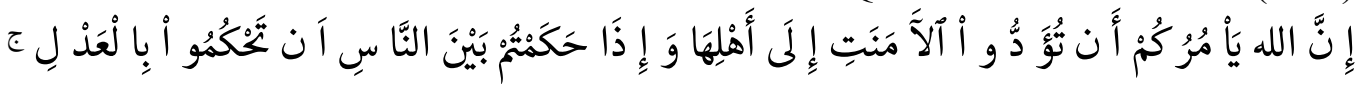

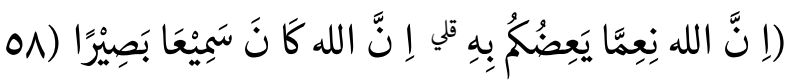

"Sesungguhnya Allah Saw menyuruh kamu menyampaikan amanat kepada yang berhak menerimanya, dan menyuruh kamu apabila menetapkan hukuman di antara manusia supaya kamu menetapkan dengan adil.Sesungguhnya Allah memberi pengajaran yang sebaik-baiknya kepadamu.Sesunggunya Allah adalah maha mendengar lagi Maha melihat."

Ayat diatas menjelaskan tentang sebuah amanat yang wajib disampaikan kepada yang wajib menerimanya bermaksud memberi amanat kepada ahlinya, yaitu orang-orang yang mempunyai keahlian dalam bidang itu sehingga dalam penempatan karyawan harus sesuai dengan kemampaunya dan keahlian karyawan tersebut.

\section{Physical Evidence (Bukti Fisik)}

Sifat jasa yang tidak nyata hanya dapat dinilai setelah dionsumsi akan meningkatkan risiko pengambilan keputusan pembelian konsumen. Dengan demikian tantangan kritis dalam pemasaran jasa membuat jasa yang lebih nyata dengan cara mengelola bukti fisik. Konsumen tidak dapat melihat jasa yang ditawarkan, tetapi dapat melihat berbagai bukti fisik yang dapat dihubungkan dengan jasa yang ditawarkan. Apabila berbagai bukti fisik ini dikelola dengan baik akan memudahkan konsumen dalam menilai jasa dan mengurangi risiko dalam mengambil keputusan pembelian (Mts.Arif, 2007:90).

Physical evidence (bukti fisik), meruapakan lingkungan fisik tempat jasa diciptakan dan langsung berinteraksi dengan konsumen. Ada dua jenis bukti fisik, yaitu: (Lupi- 
yoadi dan Hamdani, 2006:71)

1) Bukti penting (essential evidence) merupakan keputusan-keputusan yang dibuat oleh pemberi jasa mengenai desain dan tata letak (layout) dari gedung, ruang, dan lainlain.

2) Bukti pendukung (peripheral evidence) merupakan nilai tambah yang bila berdiri sendiri tidak akan berarti apa-apa. Jadi, hanya berfungsi sebagai pelengkap jasa, sekalipun demikian perananya sangat penting dalam proses produksi jasa. Contoh: tiket pesawat. Bukti fisik membantu pemasar untuk memosisikan perusahaan di pasar dan memberikan dukungan nayata apabila yang berhubungan dengan lokasi.

Allah Swt berfirman dalam Al-Qur'an surah At-Takaasur (102:1-5)

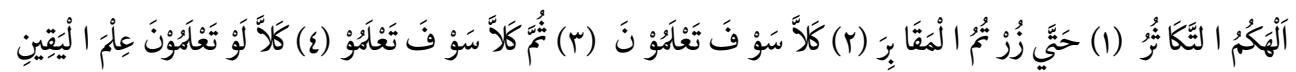

$$
\begin{aligned}
& \text { (0) لى اعيديك. لقة لعدة لإعمل والتجميلة. }
\end{aligned}
$$

"Bermegah-megah telah melalaikan kamu, sampai kamu masuk kedalam kubur. Jangan begitu, kelak nanti kamu akan mengetahui (akibat perbuatan itu), dan janganlah begitu, kelak kamu akan mengetahui. Janganlah begitu, jika kamu mengetahui dengan pengetahuan yang yakin".

Dalam konsep Islam pelayanan yang berkenaan dengan tampilan fisik hendaknya tidak menunjukkan kemewahan. Fasilitas yang membuat konsumen merasa nyaman memang penting, namun bukanlah fasilitas yang menonjolkan kemewahan.

\section{Process (Proses)}

Proses merupakan gabungan semua aktivitas, umumnya terdiri atas prosedur, jadwal pekerjaan, mekanisme, aktivitas, dan hal-hal rutin di mana jasa dihasilkan dan disampaikan kepada konsumen. Proses dapat dibedakan dalam dua cara sebagai berikut.

a. Kompleksitas (Complexity), berhubungan dengan langkah-langkah dan tahap dalam proses

b. Keragaman (Divergence), berhubungan dengan adanya perubahan dalam langkah atau tahap proses 
Sehubungan dengan dua cara tersebut, empat pilihan yang dapat dipilih oleh marketer adalah sebagai berikut.

1. Mengurangi Keragaman (Reduced Divergence)

2. Menambah Keragaman (Increased Divergence)

3. Menambah Kompleksitas (Reduced Complexity)

\section{AKAD TABUNGAN HAJI (AL - WADI'AH) \\ Pengertian Al - Wadi'ah}

Dari segi bahasa, wadi'ah adalah bentuk masdar dari fi'il madi wada'a dapat diartikan sebagai meninggalkan atau meletakkan. Yaitu meletakkan sesuatu kepada oramg lain untuk dipelihara atau dijaga. Sedangkan menurut istilah wadi'ah adalah memberikan kekuasaan kepada orang lain untuk menjaga hartanya/barangnya dengan cara terang-terangan atau dengan isyarat yang semakna dengan itu. Dalam masyarakat akad wadi'ah dikenal dengan sebuah titipan (Yazid Afandi, 2009: 193)

\section{Landasan Syari’ah}

Wadi'ah berlandaskan pada keumuman dalil al-Qur'an tentang amanah :

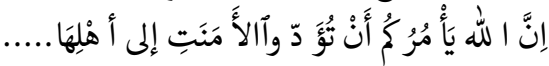

"sesungguhnya Allah telah menyuruh kamu agar menyampaikan amanah (titipan), kepada yang berhak menerimanya.....". (An-Nisa' 58)

ljma' : para ulama' dari zaman dulu sampai sekarang telah menyepakati akad wadi'ah ini karena manusia memerlukannya dalam kehidupan muamalah.

Beberapa ayat al-Qur'an yang yang dijadikan sebagai landasan hukum wadi'ah atas merupakan dalil tentang anjuran menunaikan amanah dari seseorang.Dalil di atas mencakup semua amanahyang dipikul oleh seseorang baik berupa maslah titipan maupun bukan. Maka sebenarnya dalil diakuinya wadi'ah adalah berdasarkan keumuman nash dari perlunya umat islam memikul amanah sebaik-baiknya. Wadi'ah dianggapsebagai sebuah amanah yang harus dijaga dengan baik. Melihat keumuman dalil tersebut, tidak berlebihan jika dikatakan bahwa tidak ada ayat al-Qur'an yang secara spesifik berbicara tentang wadi'ah (Yazid Afandi, 2009: 195).

\section{Metode Analisis Data}

Penelitian kualitatif adalah penelitian yang bermaksud untuk memahami fenomena tentang apa yang dialami oleh subjek penelitian misalnya prilaku, persepsi, motivasi, 
tindakan dan lain-lain. Secara holistik dan dengan cara deskriptif dalam bentuk kata-kata dan bahasa, pada suatu konteks khusus yang alamiah dan dengan manfaatkan sebagai metode alamiah. (Moleong, 2008:6).

Analisis data adalah proses mengorganisasikan dan mengurutkan data kedalam pola, kategori dan satuan uraian dasar sehingga dapat ditemukan tema dan dapat dirumuskan hipotesis kerja sehingga yang disarankan oleh data (Moleong, 2006 dalam Prastowo, 2011:238)

Analisis data menurut Patton (1980:268) dalam Basrowi dan Suwandi (2008:91) adalah proses mengatur urutan data, mengorganisasikannya ke dalam satu pola, katagori dan satuan uraian dasar.

Adapun langkah-langkah teknis analisis data dalam penelitian ini adalah sebagai berikut:

\section{Data Reduction (Reduksi Data)}

Data yang diperoleh di lapangan jumlahnya cukup banyak, untuk itu maka perlu dicatat secara teliti dan rinci. Dengan itu, dilakukan analisis data melalui reduksi data. Menurut Sugiyono (2007; 92) mereduksi data berarti merangkum, memilih hal-hal yang pokok, memfokuskan pada hal-hal yang penting, lalu dicari tema dan polanya.

Menurut Herdiansyah (2010: 165) inti dari reduksi data adalah proses penggabungan dan penyeragaman segala bentuk data yang diperoleh menjadi satu bentuk tulisan (script) yang akan dianalisis. Hasil dari wawancara, observasi dan hasil dokumentasi diubah menjadi bentuk tulisan sesuai dengan formatnya masing-masing.

2. Data display (Penyajian Data)

Setelah semua data telah diformat dalam bentuk tulisan, selanjutnya adalah melakukan display data. Display data adalah mengelola data setengah jadi hasil dari reduksi data menjadi data yang dikategorikan sesuai tema-tema yang lebih sederhana. Menurut Herdiansyah (2012: 176) dalam display data terdapat beberapa tahapan, yaitu:

1. Kategori tema, mengelompokkan tema-tema yang telah disusun dalam tebel akumulasi team wawancara. 
2. Subkategori tema, mengkategorikan data pada pecahan atau bagian tema yang lebih kecil, dan lebih mudah dimengerti.

3. Clonclusion drawing/verification

Langkah ketiga dalam analisa data kualitatif menurut Sugiyono (2007: 99) adalah penarikan kesimpulan dan verifikasi. Kesimpulan awal yang dikemukakan masih bersifat sementara, dan akan berubah bila tidak ditemukan bukti-bukti yang kuat yang mendukung pada tahap pengumpulan data berikutnya. Tetapi bila kesimpulan yang dikemukakan pada tahap awal, didukung oleh bukti-bukti yang valid dan konsisten saat peneliti kembali ke lapangan mengumpulkan data, maka kesimpulan yang dikemukakan merupakan kesimpulan yang kredibel.

\section{PEMBAHASAN HASIL PENELITIAN}

\section{Implementasi Marketing Mix Tabungan Haji}

PT. Panin Bank Syariah Tbk Cabang Malang merupakan salah satu lembaga keuangan syariah yang bergerak di bidang ekonomi yang diperuntukan bagi masyarakat pada umumnya. Semua kegiatan PT. Panin Bank Syariah Tbk Cabang Malang dapat berjalan lancar dan berkembang karena modal yang dimiliki mampu memenuhi kebutuhan yang diperlukan.Sejak awal berdirinya PT. Panin Bank Syariah Tbk Cabang Malang telah dipersiapkan untuk mencapai suatu perkembangan dengan mengacu pada mutu pelayanan.

Berdasarkan data yang telah peneliti kumpulkan , dari landasan teori dan pembahasan bab sebelumnya, peneliti menyajikan data tentang implementasi marketing mixtabungan haji pada PT. Panin Bank Syariah Tbk Cabang Malang. Bauran pemasaran atau istilah lainnya yang biasa kita kenal sebagai (marketing mix) adalah sejumlah alat-alat pemasaran yang digunakan perusahaan untuk meyakinkan obyek pemasaranyang terdiri dari Product (produk), Price (harga), Promrotion (promosi), Place (tempat/lokasi), People (orang), Physical Evidence (bukti fisik) dan Process (proses) yang masih dapat dikontrol oleh perusahaan dan dikombinasikan dalam rangka meningkatkan omset penjualan.

Impelemantasi marketing mix tabungan haji di PT. Panin Bank Syariah, Tbk Cabang Malang yaitu :

\section{Product (Produk)}

Produk adalah sesuatu yang dapat ditawarkan untuk memuaskan kebutuhan dan keninginan konsumen. Untuk memenuhi kebutuhan dan keinginan konsumen maka 
PT. Panin Bank Syariah, Tbk Cabang Malang harus memperhatiakn kepuasan nasabah melalui produk-produk yang menarik dan sesuai dengan kebutuhan nasabah.Dalam hal ini PT. Panin Bank Syariah mengelurakan produk tabungan haji yaitu produk tabungan untuk mewujudkan ibadah haji bagi mayarakat. Hal-hal yang perlu diperhatikan dalam strategi produk adalah pengembangan produk yang terpenting adalah label, pelayanannya dan jaminan produk, seperti yang dipaparkan oleh Bapak Husnan selaku LeaderMarketing pada hari kamis 2 Juni 2016 di PT. Panin Bank Syariah Tbk, Cabang Malang

"produk tabungan haji dikeluarkan untuk memenuhi keinginan dan kebutuhan nasabah, produk tabungan haji yang ada di bank syariah ini yang meluncurkan adalah kemenag pusat, sehingga produk tabungan haji yang ada di bank syariah semua itu sama, dari setoran awal sampai prosesnya tapi yang membedakan bank panin syariah dengan bank-bank syariah yang lain adalah pelayanan. Pelayanan yang kita terapkan adalah jemput bola ke nasabah, karena kebanyakan nasabah dari kita orang-orang kabupaten dan mereka sudah mempercayai bahwa produk tabungan haji PT. Panin Bank Syariah paling unggul".

Selain itu peneliti juga wawancara dengan informan atas nama Novita selaku Marketing juga pada tanggal 20 Mei 2016, menyampaikan bahwa :

"Dalam produk tabungan haji ini kita sudah mengemas produk ini sesuai dengan standart mulai dari label, jaminan sampai pelayanannya dan produk tabungan haji ini mempunyai banyak link-link ke KBIH khususnya di daerah Malang sehingga produk kami sudah banyak di kenal oleh masyarakat."

Selain itu peneliti juga wawancara dengan informan atas nama Nugroho sebagai nasabah tabungan haji pada tanggal 25 Mei 2016, menyampaikan bahwa :

"Saya sebagai nasabah tabungan haji merasa sangat puas dengan produk tabungan haji ini karena saya meraskan adanya jaminan, pelayanan yang memuaskan dan kemudahan dalam proses pembukaan rekening, pembayaran sampai pemberangkatan ibadah haji."

Menurut hasil wawancara dapat disimpulkan bahwa produk tabungan haji yanga ada di PT. Panin Bank Syariah sudah bagus mulai dari label, jaminan sampai dengan pelayanannya sehingga nasabah merasa puas dengan produk ini. 
Produk menurut Philip Kotleradalah : sesuatu yang dapat ditawarkan ke pasar untuk mendapatkan perhatian untuk dibeli, untuk digunakan atau dikonsumsi yang dapat memenuhi keinginan dan kebutuhan. Produk biasanya digunakan untuk dikonsumsi baik untuk kebutuhan rohani maupun jasmani. Untuk memenuhi keinginan dan kebutuhan akan produk, maka konsumenn harus mengorbankan sesuatu sebagai balas jasanya, misalnya dengan cara pemebelian (Kasmir, 2008: 123)

Menurut Nur rianto Al Arif (2010:16) produk dalam pemasaran syariah adalah berdaya guna, materi yang dapat dikonsumsidan yang mempunyai manfaat, bernilai guna yang menghasilkann perbaikan material, moral, spirituial bagi pelanggan.sebagaimana dapat disimak dalam firman Allah SWT.

Dalam surah Al-Baqarah (2:173).

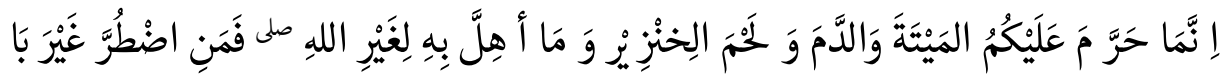

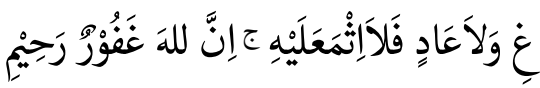

Artinya: "Sesungguhnya Allah hanya mengharamkan bagimu bangkai, darah, daging babi, dan binatang yang (ketika disembelih) disebut (nama) selain Allah, Tetapi barang siapa yang dalam keadaan terpaksa (memakannya) sehingga dia tidak menginginkannya dan tidak (pula) melampaui batas, maka tidak ada dosa baginya. Sesungguhnya Allah Maha Pengampun lagi Maha Penyayang"

\section{Price (Harga)}

Penentuan harga merupakan salah satu sangat penting dalam kegiatan pemasaran karena harga sangat menentukan laku tidaknya produk dan jasa perbankan.Dalam produk tabungan haji di PT. Panin Bank Syariah setoran awal Rp. 500.000,- dan untuk mendapatkan porsi haji Rp. 25.500.000 dan untuk menunggu pemberangkatan nasabah bisa menabung kekurangan pembayaran sesuai kemampuan sampai batas pemberangkatan.

Sesuai wawancara dengan informan atas nama Husnan selaku marketingpada tanggal 2 Juni ,bahwa :

\footnotetext{
"Harga sangat memengaruhi laku atau tidaknya produk di pasar, akan tetapi harga tabungan haji di PT. Panin Bank Syariah Tbk Cabang Malang sama dengan bank-bank lainnya hanya saja yang membedakan pada pelayanan yang di berikan PT. Panin Bank Syariah berbeda dengan yang lainnya."
}

Selain itu peneliti juga wawancara dengan informan atas nama Novita selaku Marketing juga pada tanggal 20 Mei 2016, menyampaikan bahwa : 
“Harga boleh sama akan tetapi harga di PT. Panin Bank Syariah Tbk, Cabang Malang sudah sesuai harga di pasar dan setiap tahunnya nasabah haji di PT. Panin Bank Syariah selalu meningkat."

Selain itu peneliti juga wawancara dengan informan atas nama Nugroho sebagai nasabah tabungan haji pada tanggal 25 Mei 2016, menyampaikan bahwa :

\begin{abstract}
"Saya memilih menjadi nasabah tabungan haji di PT. Panin Bank Syariah Tbk Cabang Malang karena saya merasa diistimewakan menjadi nasabah karena pelayanan yang diberikan membuat saya tertarik dengan produk ini selain itu biaya pembukan awal yang murah hanya Rp. 500.000 dan bebas biaya administrasi juga."
\end{abstract}

Dari wawancara di atas dapat disimpulkan bahwa harga sangat penting dan harga tabungan haji di PT. Panin Bank Syariah Tbk, Cabang Malang sesui dengan harga pasar mulai dari biaya pembukaan yang hanya Rp. 500.000 , bebas biaya administrasi dan pelayanan yang baik.

Penentuan harga merupakan salah satu aspek penting dalam kegiatan pemasaran. Harga menjadi sangat penting untuk diperhatikan, mengingat harga sangat menentukan laku tidaknya produk dan jasa perbanka. Salah dalam menentukan harga akan berakibat fatal terhadap produk yang ditawarkan nantinya (Kasmir, 2010: 135)

Dalam hadis diceritakan bahwa Abu Hurairah juga menuturkan, pernah seorang laki-laki mendatangi Rsulullah SAW la lalu berkata, "Ya Rasulullah, tetapkanlah harga.” Rasulullah menjawab, "Akan tetapi, aku hanya akan berdoa kepada Allah.” Lalu datang orang lain berkata, "Ya Rasulullah, tetapkanlah harga" Beliau menjawab:<smiles>C#CC[Al]</smiles>

"Akan tetapi, Allahlah Yang menurunkan dan menaikkan harga". (HR Ahmad dan ad-Darimi)

Dari hadis diatas dapat disimpulkan bahwa penetapan harga dengan cara dan karena alasan yang tidak tepat, merupakan suatu ketidakadilan yang akan dituntut pertanggungjawabanya di hadapan Allah.

\title{
Place (Lokasi)
}

Lokasi adalah tempat dimana diperjualbelikannya produk perbankan.Langkah awal dalam perencanaan pemasaran adalah penentuan lokasi.Lokasi mempunyai peranan 
yang sangat penting dan menunjang perkembangan perusahaan dan lokasi juga menjadi penentu keberhasilan suatu perusahaan, maka PT. Panin Bank Syariah Tbk Cabang Malang harus benar-benr menentukan lokasi yang strategis agar dapat dijangkau oleh nasabah.

PT. Panin Bank Syariah Tbk Cabang Malang terletak di jalan satu arah di Jl. Mgr. Sugiopranoto No. 7 Malang, Jawa Timur Telp.(0341) 361383 fax.(0341) 361861.PT. Panin Bank Syariah Tbk Cabang Malang juga memiliki kantor yang nyaman, bersih, rapi dan memiliki tempat parkir yang luas.

Sesuai wawancara dengan informan atas nama Husnan selaku marketingpada tanggal 2 Juni ,bahwa :

"Penentuan lokasi akan menetukan sejumlah keuntungan-keuntungan, seperti perusahaan akan berada pada posisi yang kuat dalam persaingan dan kemampuan pelayanan terhadap kebutuhan dan keinginan nasabah terpenuhi.Meskipun lokasi PT. Panin Bank Syariah terletak di jalan satu arah tetapi tidak ada nasabah yang mengeluh akan keberadaan bank ini."

Selain itu peneliti juga wawancara dengan informan atas nama Novita selaku Marketing juga pada tanggal 20 Mei 2016, menyampaikan bahwa :

“ Lokasi PT. Panin Bank Syariah sangat strategis yang berada di tengah-tengah kota akan tetapi masih banyak nasbah yang tidak mengerti keberadaan PT. Panin Bank Syariah Tbk Cabang Malang dikarenakan keberadaan rumah nasabah yang berada di kabupaten Malang karena kebanyakan nasabah tabungan haji berada di kabupaten Malang yang jarang sekali berkunjung ke Kota Malang. Sehingga pihak bank yang harus berkunjung ke tempat nasabah."

Selain itu peneliti juga wawancara dengan informan atas nama Nugroho sebagai nasabah tabungan haji pada tanggal 25 Mei 2016, menyampaikan bahwa :

“keberadaan PT. Panin Bank Syariah Tbk Cabang Malang cukup terjangkau dari tempat tinggal saya karena tempat tinggal saya berada di daerah kota Malang sehingga saya tidak kebingungan untuk mrncari lokasinya. Tetapi sebagian teman saya yang bukan nasabah PT. Panin Bank Syariah Tbk Cabang Malang tidak mengetahui keberadaan PT. Panin Bank Syariah."

Dari wawancara diatas dapat disimpulkan bahwa lokasi di PT. Panin Bank Syariah sudah strategis hanya saja ada beberapa nasabah yang tidak mengetahui keberadaan 
lokasi PT. Panin Bank Syariah sehingga pihak marketing harus jemput bola ke nasbah agar citra PT. Panin Bank Syariah tetap baik karena PT. Panin Bank Syariah mengedepankan pelayanan dan kepuasn nasabah.

Bagi perbankan, pemilihan lokasi (tempat) sangat penting, dalam menentukan lokasi pembukaan kantor cabang atau kantor kas termasuk peletakkan mesin ATM, bank harus mampu mengidentifikasi sasaran pasar yang dituju berikut yang sesuai dengan core business dari perusahaan. Misalkan perbankan yang fokus pada korporat, maka harus membuka kantor perwakilannya pada lokasi-lokasi yang banyak ditempati perusahaan agar sesuai dengan tujuan perusahaan tersebut. Janganlah suatu perbankan yang fokus pada korporat namun merambah membuka kantor perwakilannya ke daerah-daerah pinggiran, karena tidak sesuai dengan core business perbankan tersebut. Peraturan Bank Indonesia terkait dengan office channeling merupakan salah satu bentuk dari bauran pemasaran pada perbankan syariah dalam hal strategi untuk mengatasi keterbatasan tempat dan jaringan yang dimiliki (Nur Rianto Al Arif, 2010: 16).

Dalam memilih lokasi tergantung dari keperluan lokasi tersebut. Terdapat paling tidak enam lokasi yang dipertimbangkan sesuai keperluan perusahaan, yaitu : (Kasmir, 2010: 149).

1. Lokasi untuk kantor pusat

2. Lokasi kantor wilayah

3. Lokasi untuk kantor cabang utama

4. Lokasi untuk kantor cabang pembantu

5. Kantor kas

6. Mesin-mesin ATM

Hal yang ingin ditekankan oleh Nabi Muhammad Saw saat itu adalah bahwa sebuah proses distribusi haruslah sesuai dengan peraturan yang telah disepakati bersama dan tidak ada pihak yang dirugikan baik dari pihak produsen, distributor, agen, penjual secara eceran dan konsumen. (Rianto, 2010:16)

Jelas sekali bahwa yang ditekankan oleh Nabi Muhammad Saw dalam penentuah lokasi tidak boleh ada pihak yang drugikan baik nasabah dan pihak bank, akan tetapi pihak bank panin syariah mengantusiasi hal tersebut dengan cara jemput bola nasbah. 


\section{Promotion (Promosi)}

Promosi merupakan sarana yang paling ampuh untuk menarik dan mempertahankan nasabahnya.

Secara garis besar ada empat macam sarana promosi yang dapat digunakan oleh perbankan adalah sebagai berikut:

\section{Periklanan (Advertising)}

Periklanan merupakan promosi yang dilakukan dalam bentuk tayangan atau gambar atau kata-kata yang tertuang dalam spanduk, brosur, billboard, koran, majalah, televisi, atau radio.

PT. Panin Bank Syariah Tbk Cabang Malang dalam menerapakan promosi periklanan lebih maksimal menggunakan brosur

Sesuai wawancara dengan informan atas nama Husnan selaku marketingpada tanggal 2 Juni ,bahwa :

“untuk di PT. Panin Bank Syariah Tbk Cabang Malang promosi menerapkan promosi periklanan hanya melalui brosur dan disebarkan ketika ada moment-moment tertentu dan karena harga nya juga relative murah untuk membuat brosur. Untuk promosi periklanan mengunakan media-media yang lebih besar masih belum bisa dilakukan karena PT. Panin Bank Syariah Tbk Cabang Malang tergolong bank baru maka masih banyak yang harus di persiapkan dan biaya yang cukup besar untuk menggunkan media iklan yang lebih besar."

Selain itu peneliti juga wawancara dengan informan atas nama Novita selaku Marketing juga pada tanggal 20 Mei 2016, menyampaikan bahwa :

"PT. Panin Bank Syraiah Tbk Cabang Malang masih belum menggunakan semua promosi melalui iklan karena biaya yang mahal dan sampai saat ini masih menggunkan brosur."

\section{Promosi Penjualan (Sales Promotion)}

Promosi penjualan merupakan promosi yang digunakan untuk meningkatakan penjualan melalui potongan harga atau hadiah pada waktu tertentu terhadap barang-barang tertentu pula. 
PT. Panin Bank Syariah Tbk Cabang Malang menggunakan strategi sales promotion dengan mengadakan pameran prosuk dan sosialisai ke lembaga-lembaga dan memberikan hadiah.

Selain itu peneliti juga wawancara dengan informan atas nama Novita selaku Marketing juga pada tanggal 20 Mei 2016, menyampaikan bahwa :

“PT. Panin Bank Syariah Tbk Cabang Malang sering mengadakan pameran di mall dan pemberian hadiah bagi nasabah yang membuka rekening”.

\section{Publisitas (Publicity)}

Publisitas merupakan promosi yang dilakukan untuk meningkatkan citra bank di depan para calon nasabah atau nasabahnya melalui kegiatan sponsorship terhadap suatu kegiatan amal atau sosial.

PT. Panin Bank Syariah menerapakan strategi publisitas dengan cara presentasi ke forum KBIH dan nasabah retail tujuannya agar nasabah mengenal bank lebih dekat.

Sesuai wawancara dengan informan atas nama Husnan selaku marketingpada tanggal 2 Juni ,bahwa :

\footnotetext{
"Salah satu cara bentuk PT. Panin Bank Syariah mengenalkan lebih dekat produk tabungan haji dengan berkunjung ke KBIH karena PT.Panin Bank Syariah Tbk Cabang Malang sudah mempunyai banyak relasi KBIH yang ada di Malang dan juga pernah memberikan santunan ke Yayasan Manbaul Khairat Malang."
}

Selain itu peneliti juga wawancara dengan informan atas nama Novita selaku Marketing juga pada tanggal 20 Mei 2016, menyampaikan bahwa :

“PT. Panin Bank Syariah Tbk Cabang Malang sudah menerapakan publisitas dengan berkunjung ke KBIH dan mempunyai banyak relasi $\mathrm{KBIH}$ yang ada di Malang guna meningkatkan dan mempertahankan nasabah tabunga haji."

\section{Penjualan Pribadi (Personal Selling)}

Personal Sellingmerupakan promosi yang dilakukan melalui pribadi-pribadi karyawan bank dalam melayani serta ikut memengaruhi nasabah.

Di PT. Panin Panin Bank Syariah Tbk Cabang Malang semua karyawan bisa menggunakan promosi atau menawarkan produk secara pribadi langsung ke nasabah atau 
calon nasbah.

Sesuai wawancara dengan informan atas nama Husnan selaku marketingpada tanggal 2 Juni ,bahwa :

“Penjualan pribadi bisa dilakukan oleh semua karyawan baik di luar jam kerja melalui telle marketing dari relasi yang didapat teman atau kerabat (internal aatu eksternal) dan yang paling terpenting dalam penjualan pribadi ini menjaga silaturahmi dengan nasabah agar nasabah merasa diperhatikan oleh pihak bank dan tetap menjadi nasabah PT. Panin Bank Syariah."

Selain itu peneliti juga wawancara dengan informan atas nama Novita selaku Marketing juga pada tanggal 20 Mei 2016, menyampaikan bahwa :

"PT. Panin Bank Syariah Tbk Cabang Malang sudah menerapkan sistem tersebut dengan baik, bukan hanya marketing akan tetapi semua karyawan bisa melakukan personal selling."

Dari wawancara dengan informan atas nama Nugroho pada tanggal 25 Mei 2016 sebagai nasabah, bahwa:

\footnotetext{
"saya sering mengetahui bahwa panin syariah mengadakan pameran di mall dan berkunjung ke KBIH dan saya juga mendapatkan brosur tabungan haji di event-event tertenut tetapi saya belum pernah mengetahui sosialiasai bank panin syariah di iklan di tv atau radiio seperti bank-bank lainnya."
}

Dari wawancara diatas dapat disimpulkan bahwa promosi di PT. Panin Bank Syariah Tbk, Cabang Malang sudah bagus hanya saja kurangnya promosi media sosial seperti radio , televisi agar masyarakat lebih mengetahui lagi adanya PT. Panin Bank Syariah Tbk, Cabang Malang.

Promosi merupakan sarana yang paling ampuh untuk menarik dan mempertahankan nasabahnya.Salah satu tujuan promosi bank adalah menginformasikan segala jenis produk yang ditawarkan dan berusaha menarik calon nasabah yang baru.Dalam kegiatan ini setiap bank berusaha untuk mempromosikan seluruh produk dan jasa yang dimilikinya baik langsung maupun tidak langsung. Kemudian promosi juga berfungsi mengingatkan nasabah akan produk, promosi juga ikut memengaruhi nasabah untuk membeli dan akhirnya promosi juga akan meningkatkan citra bank di mata para nasabahnya (Kasmir , 2010: 155) 
Dalam konsep syariah dalam promosi juga dijelaskan dalam Firman Allah Swt AlQur'an surah An-Nisaa' (4:29)

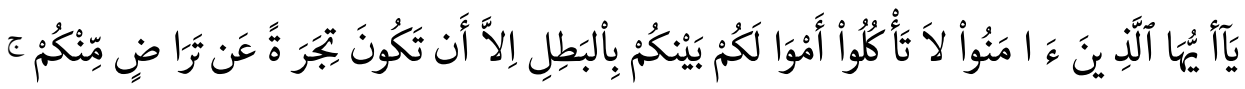

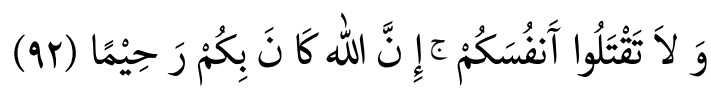

"Hai orang-orang yang beriman, janganlah kamu saling memakan harta sesamamu dengan jalan yang batil, keceuali dengan jalan perniagaan yang dapat berlaku denganjalan kamu, dan janganlah kamu membunuh dirimu.Sesunggunya Allah adalah maha penyayang kepadamu."

\section{People (orang)}

Pentingnya people dalam pemasaranjasa berkaitan erat dengan internal marketing. Internal marketing adalah interaksi atau hubungan antara setiap karyawana dengan departemen dalam suatu perusahaan yang dalam hal ini dapat diposisikan sebagai internal customer dan internal supplier.

Berdasarkan hsail wawancara dengan informan atas nama Novita selaku Marketing, bahwa:
"Hubungan antara tim marketing di PT. Panin Bank Syariah Tbk, Cabang Malang sangat kompak karena disini kami mempunyai tim leader yang san- gat luar biasa, kadang kami anggap beliauseperti bapak sendri kadang se- bagai teman karena setiap tim terlihat kompak atau tidaknya tergantung pada leader dari masing-masing tim karena ketika di dalam satu tim interaksi antara pegawai satu dengan yang lainnya baik maka komunikasi atau inter- aksi dengan nasbah pasti baik."

Sesuai wawancara dengan informan atas nama Husnan selaku marketingpada tanggal 2 Juni ,bahwa:

“Di PT. Panin Bank Syariah Tbk Cabang Malang mempunyai karyawan atau SDM yang handal, disiplin, ramah dan hubungan anatar internal tim juga bagus sehingga karyawan bisa bekerja sesuai job description dan professional."

Selain itu peneliti juga wawancara dengan informan atas nama Nugroho sebagai nasabah tabungan haji pada tanggal 25 Mei 2016, menyampaikan bahwa :

"Saya mengenal betul dengan Bapak Husnan, beliau seorang marketing yang paling saya akrab, karena beliau sangat menguasai produk yang dijelaskan, beliau juga hu- 
moris sehingga sangat nyaman dan tidak bosan ketika sharing-sharing dengan beliau."

Dari wawancara diatas dapat disimpulkan bahwa SDM yang ada di PT. Panin Bank Syariah sudah memenuhi kriteria dan hubungan karyawan dengan nasabah sudah cukup bagus sehingga nasabah merasa puas.

Untuk mencapai kualitas yang terbaik, pegawai harus dilatih untuk menyadari pentingnya pekerjaan mereka, yaitu memberikan konsumen kepuasan dalam memenuhi kebutuhannya.Pentingnya people dalam pemasaran jasa berkaitan erat dengan internal marketing.Internal marketing adalah interaksi atau hubungan antara setiap karyawana dengan departemen dalam suatu perusahaan yang dalam hal ini dapat diposisikan sebagai internal customer dan internal supplier.Tujuan adanya hubungan tersebut adalah untuk mendorong people dalam kinerja memberikan kepuasan kepada konsumen. (Mts.Arif, 2007:98).

Ayat-ayat Al-Qur'an yang menjelaskan tentang SDM yang tepat. Allah SAW berfirman Al-Qur'an surah An-Nisaa' (4:58)

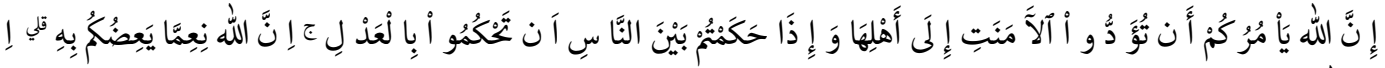

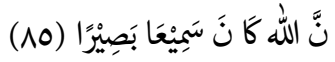

"Sesungguhnya Allah SAWmenyuruh kamumenyampaikan amanat kepada yang berhak menerimanya, dan menyuruh kamu apabila menetapkan hukuman di antara manusia supaya kamu menetapkan dengan adil.Sesungguhnya Allah memberi pengajaran yang sebaik-baiknya kepadamu. Sesunggunya Allah adalah Maha Mendengar lagi Maha Melihat."

\section{Physical Evidence (Bukti Fisik)}

Physical evidence (bukti fisik), meruapakan lingkungan fisik tempat jasa diciptakan dan langsung berinteraksi dengan konsumen. Ada dua jenis bukti fisik, yaitu: (Lupiyoadi dan Hamdani, 2006:71)

1. Bukti penting (essential evidence) merupakan keputusan-keputusan yang dibuat oleh pemberi jasa mengenai desain dan tata letak (layout) dari gedung, ruang. Di PT. Panin Bank Syariah mempunyai gedung yang besar dan halaman yang luas. Tata letak ruangan sesuai dengan yang dibutuhkan tetapi banyak ruangan yang tidak terpakai

2. Bukti pendukung (peripheral evidence) merupakan nilai tambah yang bila berdiri sendiri tidak akan berarti apa-apa. Jadi, hanya berfungsi sebagai pelengkap jasa, seka- 
Firda, Early, Uun, Fadlil: Marketing Mix

lipun demikian perananya sangat penting dalam proses produksi jasa.

Sesuai wawancara dengan informan atas nama Husnan selaku marketing pada tanggal 2 Juni ,bahwa:

\begin{abstract}
"Saya selama bekerja di PT. Panin Bank Syariah Tbk Cabang Malang merasa nyaman berada disini dan gedung yang sangat besar ini adalah bukti fisik penting pada PT. Panin Bank Syariah Tbk Cabang Malang, disisi lain di dalam gedung ini masih ada ruangan yang tidak terpakai. Dan bukti fisik pada produk tabungan haji bukti yang harus di terima oleh nasbah haji adah berupa buku tabungan dan apabila tabungan nasbah sudah mencapai Rp. 25.500.000 nasabah sudah bisa mendapatkan porsi pemberagkatan haji,"
\end{abstract}

Selain itu peneliti juga wawancara dengan informan atas nama Novita selaku Marketing juga pada tanggal 20 Mei 2016, menyampaikan bahwa :

"PT. Panin Bank Syariah Tbk, Cabang Malang memiliki gedung yang luas selain itu mempunyai tempat parkir yang luas dan suasan di dalam ruangan nyaman"

Selain itu peneliti juga wawancara dengan informan atas nama Nugroho sebagai nasabah tabungan haji pada tanggal 25 Mei 2016, menyampaikan bahwa :

\footnotetext{
"Benar sekali setelah saya mendaftar tabungan haji di PT. Panin Bak Syariah saya langung mendapatkan buku tabungan haji dan dan pada hari itu juga saya mendapatkan porsi pemberangkatan haji saya karena penyetoran awal tabungan saya senilai 25.500 .000 dan saya akui pelayanannya sangat memuaskan sekali dan prosesnya juga cepat dan untuk masalah ruanagan yang ada di PT. Panin Bank Syariah Tbk Cabang Malang yang saya tahu hanya tempat teller dan cs dan mempunyai gedung yang besar dan parkiran yang cukup luas.
}

Konsumen tidak dapat melihat jasa yang ditawarkan, tetapi dapat melihat berbagai bukti fisik yang dapat dihubungkan dengan jasa yang ditawarkan.Apabila berbagai bukti fisik ini dikelola dengan baik akanmemudahkan konsumen dalam menilai jasa dan mengurangi risiko dalam mengambil keputusan pembelian (Mts.Arif, 2007:90).

\title{
Process (Proses)
}

Proses merupakan gabungan semua aktivitas, umumnya terdiri atas prosedur, jadwal pekerjaan, mekanisme, aktivitas, dan hal-hal rutin di mana jasa dihasilkan dan disam- 
paikan kepada konsumen.

Sesuai wawancara dengan informan atas nama Husnan selaku marketingpada tanggal 2 Juni ,bahwa :

\begin{abstract}
“proses pemberangkatan ibadah haji di PT. Panin Bank Syariah Tbk Cabang Malag yaitu dengan melalui bebarapa proses yang pertama ketika orang ingin berangakat haji harus membuka Tabungan Haji Panin Bank Syaria s/d Rp. 25.500.000 dan Tabungan. BPS-BPIH (untuk mendapatkan porsi) selanjutnya yaitu pergi ke Kemenag untuk mengsisi SPPH setealah itu kembali ke BPS-BPIH untuk menginput data SPPH sesuai KTP domisili untuk mendapatkan porsi haji setelah itu sambil menunggu waktu keberangkatan haji sesuai quota wilayah, dapat menabung untuk persiapan pelunasan sekitar Rp. 12.000.000 s/d Rp. 15.000.000."
\end{abstract}

Selain itu peneliti juga wawancara dengan informan atas nama Novita selaku Marketing juga pada tanggal 20 Mei 2016, menyampaikan bahwa :

"Proses yang dilakukan oleh PT. Panin Bank Syariah Tbk Cabang Malang sudah sesuai dengan peraturan dan untuk proses pemberangkatan haji sepenuhnya nasabah tidak mengerti karena semua yang mengurusi tim marketing haji yang bekerjasama dengan KBIH-KBIH."

Selain itu peneliti juga wawancara dengan informan atas nama Nugroho sebagai nasabah tabungan haji pada tanggal 25 Mei 2016, menyampaikan bahwa :

"Saya hanya mengerti bagaimana proses untuk pembukaan rekening tabungan haji dan proses selanjutnya saya serahkan langsung ke KBIH dan langsung menyetorkan uang disana Karena untuk pemberangkatan sepenuhnya saya percayakan kepada KBIH dan saya hanya tinggal menerima buku tabungan dan kapan waktu untuk pemberangkatan ibadah haji."

Menurut Mts.Arif (2007:99) Proses merupakan gabungan semua aktivitas, umumnya terdiri atas prosedur, jadwal pekerjaan, mekanisme, aktivitas, dan hal-hal rutin di mana jasa dihasilkan dan disampaikan kepada konsumen. Proses dapat dibedakan dalam dua cara sebagai berikut.

1. Kompleksitas (Complexity), berhubungan dengan langkah-langkah dan tahap dalam proses 
Firda, Early, Uun, Fadlil: Marketing Mix

2. Keragaman (Divergence), berhubungan dengan adanya perubahan dalam langkah atau tahap proses.

\section{KENDALA DAN SOLUSI YANG DIHADAPI DALAM IMPLEMENTASI MARKETING MIX TABUNGAN HAJI DI PT. PANIN BANK SYARIAH TBK CABANG MALANG}

Kendala yang dihadapi oleh PT. Panin Bank Syariah Tbk Cabang Malang dalam implementasi marketing mix tabungan haji adalah dari segi lokasi PT. Panin Bank Syariah Tbk Cabang Malang selain itu dalam mempromosikan produk seingkali terkendala waktu.

Sesuai wawancara dengan informan atas nama Husnan selaku marketing pada tanggal 2 Juni ,bahwa:
“PT. Panin Bank Syariah Tbk Cabang Malang yang terletak di Jl. Mgr. Sugio- pranoto No. 7 Malang Jawa Timur Phone (0341) 361383 Fax (0341) 361861. Memiliki jalan satu arah sehingga sebagian orang tidak mengetahui ke- beradaan bank, selain itu kebanyakan nasabah yang berada di kabupaten Malang dan yang jarang sekali berkunjng ke kota Malang pasti akan kebi- ngunganapabila sudah di Tanya keberadaan PT. PAnin Bankm Syariah Tbk Cabang Malang."

Selain itu peneliti juga wawancara dengan informan atas nama Novita selaku Marketing juga pada tanggal 20 Mei 2016, menyampaikan bahwa :

\footnotetext{
“kendala yang sering terjadi dalam memasarkan tabungan haji ini waktu yang sering benturan ke KBIH-KBIH karena banyaknya jamaah haji yang harus di handle oeh tim kami."
}

Dari kendala di atas solusi yang dilakukan oleh PT. Panin Bank Syariah Tbk Cabang Malang harus melakukan strategi yang harus dilakuakan oleh tim marketing agar para nasabah tidak kecewa dan tetap menjadi nasabah di PT. Panin Bak Syariah Tbk Cabang Malang .

Sesuai wawancara dengan informan atas nama Husnan selaku marketing pada tanggal 2 Juni ,bahwa :

\footnotetext{
“Ketika ada nasabah kami, yang tidakmengetahui lokasibankmaka kamiselalu membuatstrategi,strategiyangkamilakukanyaitujemputbolakenasabahyang ingin benar-benar menjadi nasabah PT. Panin Bank Syariah Cabang Malang."
} 
Selain itu peneliti juga wawancara dengan informan atas nama Novita selaku Marketing juga pada tanggal 20 Mei 2016, menyampaikan bahwa :

"solusiuntuk masalah kami yang sering bebenturan waktu dengan waktu nasbah dalam memrmosikan produk tabungsn haji maka kami atau satu tim marketingharus bisa memanajemen waktu berkunjung ke KBIH atau menemui nasabah dan menanggung resiko ketika kita harus memilih salah satu dari dua pilihan."

Demikian paparan diatas mengenai implementasi marketing mix tabungan haji pada PT. Panin Bank Syariah Tbk cabang Malang bahwa semua marketing mixsudah bisa di terapkan dengan baik oleh PT. Panin Bank Syariah Tbk Cabang Malang tetapai dalam implementasinya harus disesuaikan dengan sasaran seperti orang dan tempat yang akan dituju.

\section{KESIMPULAN}

Berdasrkan hasil observasi, wawncara dan dokumentasi di PT. Panin Bank Syariah Tbk Cabang Malang maka dapat disimpulkan sebagai berikut :

PT. Panin Bank Syariah Tbk Cabang Malang sudah menerapakan semua marketing mix dan PT. Panin Bank Syariah Tbk, Cabang Malang berusaha meningkatkan marketing mix dengan cara penerapan produk, harga, peningkatan promosi, menentukan lokasi yang strategis, penerapan people, bukti fisik dan penerapan proses untuk meningkatkan perkembangan nasabah haji dan PT. Panin Bank Syariah Tbk Cabang Malang memberikan inovasi-inovasi produknya agar diminati oleh nasabah seperti memberikan reward kepada nasabahdanmarketing mix ini diterapkan dengan dijadikan satu kegiatan yang diberikan kepada nasabah. 7P (Product, Price, Promotion, Place, People, Physical Evidence dan Process) dikemas malalui satu program atau event kemudian di proses menjadi satu sehingga 7P ini menjadi satu-kesatuan yang dapat langsung dipahami oleh nasbah haji.

Kendala yang dihadapi oleh PT. Panin Bank syariah Tbk Cabang Malang dalam implementsi marketing mix adalah dari segi lokasi yang masih banyak orang tidak mengetahui lokasinya sehingga tim marketing haji harus jemput bola kepada calon nasabah atau nasabahnya, serta dalam promosi tim marketing sering ada waktu yang benturan karena harus menghandle jamaah haji lainnya. Dan Solusi dari kendala implementasi sebagian orang ada yang tidak mengetahui lokasi PT. Panin Bakn Syariah Tbk CabangMalang maka pihak marketing mengandalkan sistem jemput bola agar mendapatkan nasbah dan tetap menjadi nasabah di PT. Panin Bank Syariah. Dalam 
Firda, Early, Uun, Fadlil: Marketing Mix

promosi tim marketing hraus bisa mengahndle waktu nasbah yang terbenuran sehingga tidak ada pihak yang dirugikan. Dengan adanya penerapan marketing mix bisa menigkatkan jumlah nasabah tabungan haji dan dengan mengetahui kelemahan $7 \mathrm{P}$ (Product, Price, Promotion, Place, People, Physical Evidence dan Process) dapat menjadi evaluasi dan dapat diperbaiki selnjutnya. 


\section{DAFTAR PUSTAKA}

Afandi, M Yazid. (2009), Fiqh Muamalah. Yogyakarta: Logung Printika.

Al Arif, M NurRianto. (2010), Dasar-Dasar Pemasaran Bank Syariah. Bandung: Alfabeta. Arief, Mts. (2007), Pemasaran Jasa Kualitas Pelayanan. Malang: Bayumedia Publishing. Armeliyanti, Lucky.(2012), "Penerapan Strategi Marketing Mix Terhadap Perkembangan ProdukUmroh".

Basrowi., Suwandi. (2008), Memahami Penelitian Kualitatif. Jakarta: Rineka Cipta Firmansyah, Aji. (2016), “Analisis Implementasi Strategi Marketing Mix Pada Manajemen Pemasaran".

Hasan, Ali. (2010), Marketing Bank Syariah. Bogor: Ghalia Indonesia

Herdiansyah, Haris. (2012). Metodologi Penelitian Kualitatifuntuk Ilmu-ilmusosial. Jakarta: Penerbit Salemba Empat.

Kasmir.(2010), Pemasaran Bank. Jakarta: Prenada Media Group

Kotler, Philip. (2000), Marketing Management, The Millennium Edition. New Jersey: Prentice Hall.

Lexy, J Moleong.(2008), Metode Penelitian Kualitatif. Bandung: Remaja Rosdakarya.

Lupiyodi, Rambat., Hamdani A. 2006, Manajemen Pemasaran Jasa. Depok: Salemba Empat

Machmud, Amir.,Rukmana. (2010), Bank Syariah. Jakarta: Erlannga.

Muhammad. (2008), Metode Penelitian Ekonomi Islam. Jakarta: PT. Raja grafindo Persada.

Nuvitasari, Erma. (2015), “Implementasi Strategi Bauran Pemasaran Pada Produk Tabungan Barokah".

Prastowo, Andi. (2011). Metode Penelitian Kualitatif dalam Prespektif Rancangan Penelitian.Jakarta: AR-RUZZ MEDIA.

Purnamasari, Irma Devita., Suswinarno. (2011), AkadSyariah. Bandung: Kaifa

Sugiyono, (2007), Metode Penelitian Kualitatif. Bandung: Alfabeta.

Sugiyono.(2010), Metode Penelitian Pendidikan. Bandung: Alfabeta.

Supriyanto, AchnadSani., Machfudz, Masyhuri. (2010), Metodologi Riset Manajemen Sumberdaya Manusia. Malang: UIN Maliki Press.

Winardi.(1989), Ilmudan Seni Menjual. Bandung: Nova. 